\title{
Internet access and utilisation of adolescents attending a national centre for paediatric rheumatology
}

\author{
Derek Deely ${ }^{*}$ Emma MacDermott, Orla Killeen \\ From 21st European Pediatric Rheumatology (PReS) Congress \\ Belgrade, Serbia. 17-21 September 2014
}

\begin{abstract}
Introduction
With emerging interactive and communication technologies now available, the internet has become one of the top health information resources for adolescents (Stinson et al., 2010). Adolescents are typically the early adapters of new technologies, with in particular, the internet providing innovative opportunities for engaging youths. Traditional sources of health information are now becoming defunct and young people are increasingly going online for health related information.
\end{abstract}

\section{Objectives}

To assess internet access and utilisation of adolescents.

\section{Methods}

A convenience sample of 25 patients completed an online questionnaire. The questionnaire assessed the following: 1. Adolescents access and utilisation of the internet. 2. Adolescents utilisation of the internet to access health related information.

\section{Results}

From the 25 respondents $52 \%$ were female, $48 \%$ male. The mean age was 14.5 years (S/D: $11-18$ years).

\section{Access \& utilisation of the internet}

$100 \%$ stated they have access to the internet on a daily basis with $85 \%$ using the internet 7 days per week. The reported time spent online ranged from 1 to 9 hours per day, mean: 2.9 hours. Table 1.

Table 1. Respondents had numerous ways to access the internet:

\footnotetext{
National Centre for Paediatric Rheumatology, Our Lady's Children's Hospital
} Crumlin, Dublin 12, Ireland
$65 \%$ stated they use the internet to look up health information. Of these, $85 \%$ researched their own medical condition/diagnosis followed by medications (35\%), pain/ coping with pain $(21 \%)$, other medical conditions $(21 \%)$, alcohol and medication (14\%) and sexual health (7\%).

When asked to list recent search items used to look up health information the following were listed: pain, explaining arthritis to others, drinking alcohol on methotrexate, hypermobility syndrome, lupus, methotrexate, medications and pregnancy, and TNF medications.

$52 \%$ of respondents use the internet to communicate with peers who have a similar diagnosis. Of these, 100\% use a facebook page linked with a community support group for adolescents and young people with rheumatic diseases.

\section{Conclusion}

The internet has become an important tool for many people with health concerns; adolescents being no

\section{related information}


exception. Health professionals must know how to guide and advise adolescents in need of health related information to material that is both reputable and of a high standard while being age appropriate and appealing (Skinner et al., 2003).

\section{Disclosure of interest}

None declared.

Published: 17 September 2014

doi:10.1186/1546-0096-12-S1-P301

Cite this article as: Deely et al.: Internet access and utilisation of adolescents attending a national centre for paediatric rheumatology. Pediatric Rheumatology 2014 12(Suppl 1):P301.

Submit your next manuscript to BioMed Central and take full advantage of:

- Convenient online submission

- Thorough peer review

- No space constraints or color figure charges

- Immediate publication on acceptance

- Inclusion in PubMed, CAS, Scopus and Google Scholar

- Research which is freely available for redistribution

Submit your manuscript at www.biomedcentral.com/submit 